\title{
La justicia abundante Nota sobre las antítesis del sermón de la montaña
}

\author{
Dean Brackley \\ Centro de Reflexión Teológica \\ San Salvador
}

Las antítesis del sermón de la montaña juegan un papel importante en el evan gelio de Mateo (5, 21-48). Exponen la justicia del reino de Dios, proclamado por Jesús. "Justicia" — o "rectitud" - es para Mateo un tema central ${ }^{1}$. Significa la voluntad de Dios, el propósito único de la torah o ley.

En Mateo Jesús insiste en la validez de esta ley hasta en sus detalles (cfr 5 , 18-19). La razón más probable es que, quizás dentro de la misma comunidad de $\mathrm{Mateo}^{2}$, un grupo de discípulos estaría afirmando que Jesús habría desechado algunos preceptos de la ley, minando así toda la torah, con lo cual el grupo disidente coincidiría con los adversarios judíos. Mateo responde que Jesús es el mesías, y que, lejos de abolir la torah y los profetas, vino a darles cumplimiento en la práctica y a explicar su sentido pleno y definitivo $(5,17)$. Pero insiste en que esa justicia del reino es abundante, y supera a la que predican los maestros judíos, los "escribas y fariseos" $(5,20)$. Por eso, las seis antítesis comienzan "han oído que se dijo", a lo que Jesús añade "pero yo les digo"3.

1. Cfr. 3,$15 ; 5,6.10 .20 ; 6,1.33 ; 21,32$. Dikaiosune corresponde a sedeq o sedeqah en hebreo. Tiene un significado general pero siempre implica la praxis concreta en el contexto de relaciones sociales.

2. Es decir, los destinatarios de este evangelio. Aquí "Mateo" se refiere al evangelista, sean uno o más los redactores.

3. "Han oído decir que se dijo a los antepasados ..." (Mt 5, 21; etc.). "Se dijo" es un "pasivo divino", que significa "Dios dijo". "Antepasados" se refiere, probablemente, a la generación de Moisés. 
Veamos el texto sobre el que vamos a reflexionar - lo esencial de las antítesis-, precedido por su introducción:

(20) Porque les digo que, si su justicia no abunda más que la de los escribas y fariseos, no entrarán en el reino de los cielos.

(21) Han oído que se dijo a los antepasados: "No matarás"; y aquel que mate será reo ante el tribunal. ${ }^{(22)}$ Pero yo les digo: Todo aquel que se encolerice contra su hermano(a), será reo ante el tribunal; y el que llame a su hermano(a) "imbécil", será reo ante el Sanedrín; y el que le llame "renegado", será reo de la gehenna de fuego.

(27) Han oído que se dijo: "No cometerás adulterio". (28) Pero yo les digo: Todo el que mira a una mujer deseándola, ya cometió adulterio con ella en su corazón.

(31) También se dijo: "El que repudie a su mujer, que le dé acta de divorcio". (32) Pero yo les digo: Todo el que repudia a su mujer, excepto en caso de fornicación, la hace ser adúltera; y el que se case con una repudiada, comete adulterio.

(33) Han oído también que se dijo a los antepasados: "No perjurarás, sino que cumplirás al Señor tus juramentos". (34) Pero yo les digo que no juren en modo alguno. ${ }^{(37)}$ Sea su lenguaje: "Sí, sî", "no, no"; que lo que pasa de aquí viene del Maligno.

(38) Han oído que se dijo: "Ojo por ojo y diente por diente". ${ }^{(39)}$ Pero yo les digo: no resistan al mal; antes bien, al que te abofetee en la mejilla derecha ofrécele también la otra; ${ }^{(40)}$ al que quiera pleitear contigo para quitarte la túnica dale también el manto; ${ }^{(41)}$ y al que te obligue a andar una milla vete con él dos. ${ }^{\left({ }^{2}\right)}$ A quien te pida da, y al que desee que le prestes algo, no le vuelvas la espalda.

(43) Han oído que se dijo: "Amarás a tu prójimo y odiarás a tu enemigo". (44) Pero yo les digo: Amen a sus enemigos y rueguen por los que los persiguen, ${ }^{(45)}$ para que sean hijos e hijas de su Padre celestial, que hace salir su sol sobre malos y buenos, y llover sobre justos e injustos. (48) Ustedes, pues, sean perfectos como es perfecto su Padre celestial.

En este artículo queremos mostrar que estas antítesis esbozan cómo deben vivir en comunidad los discípulos de Jesús. Así entendidas, expresan una invitación y un reto a las comunidades cristianas de hoy para ser, en verdad, sal de la tierra y luz del mundo. Para comprenderlo así, es necesario reconocer que las antítesis tienen una estructura más sistemática y abarcadora de lo que se suele hacer. Lo que vamos a mostrar, comparándolas con los mandamientos mencionados por Jesús en su respuesta al joven rico (Mt 19, 16-21). 


\section{El caso del joven rico}

A alguien que le pregunta a Jesús: “¿Qué he de hacer de bueno para conseguir vida eterna?", Jesús responde que sólo Dios es bueno. "Más si quieres entrar en la vida, guarda los mandamientos ... No matarás, no cometerás adulterio, no robarás, no levantarás falso testimonio, honra a tu padre y a tu madre, y amarás a tu prójimo como a ti mismo". El joven responde: "Todo eso lo he guardado; ¿qué más me falta?". Y Jesús responde: "Si quieres ser perfecto, anda, vende lo que tienes y dáselo a los pobres, y tendrás un tesoro en los cielos (es decir, guardado junto a Dios), después ven y sígueme".

Es evidente por el contexto que los preceptos mencionados por Jesús son abarcadores y globalizantes, resumen el mínimo de la ley moral. Y todos son preceptos de la "segunda tabla" del decálogo - las obligaciones con el prójimo- menos el último: "amarás a tu prójimo como a ti mismo", que proviene de Levítico 19, 18. Llama la atención la omisión de los preceptos de la "primera tabla", que se refieren directamente a Dios y el sábado. También se omite el mandamiento final del decálogo sobre la codicia de bienes (y de mujeres) ajenos.

También es llamativo el orden en que se citan los mandamientos del decálogo, pues se aparta del orden de las dos versiones veterotestamentarias (Exodo 20 y Deuteronomio 5). Estas tienen un orden bien conocido:

1) Honra a tu padre y a tu madre.

2) No matarás.

3) No cometerás adulterio.

4) No robarás.

5) No darás testimonio falso contra tu prójimo.

En las tres versiones de la historia del joven rico - en Mateo, Marcos y Lucas -, el primer precepto, honrar a padre y madre, ha pasado al final de la secuencia. En Mateo el orden es 2, 3, 4, 5, 1, que sigue a Marcos, omitiendo "no

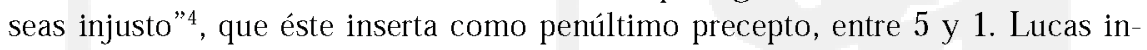
vierte 2 y 3 , y la secuencia queda $3,2,4,5,1^{5}$.

4. R. H. Gundry considera que Marcos inserta "no seas justo" (o "no defraudes") en sustitución de "no codiciarás", como mandamiento final del decálogo. ¿Por qué? Tal vez porque el joven, que es rico, afirma en el versículo siguiente que ha guardado todos estos mandamientos, lo que sería poco realista si se incluyera la prohibición de la codicia. R. H. Gundry, Mark: A Commentary on His Apology for the Cross, Grand Rapids, 1993, p. 553.

5. La Septuaginta también se aparta del texto hebreo. Las dos versiones desplazan "no matarás" (2). La secuencia en Ex 20 (LXX) es 1, 3, 4, 2, 5; en Dt 5 (LXX) es 1, 3, 2, 4,5 . 
La observancia de estos mandamientos es indispensable, evidentemente, para la vida social. A lo largo de la historia han servido para resumir los deberes más básicos para que dicha convivencia sea posible. Pero en la perícopa del joven rico, son además indispensables, aunque no suficientes, para alcanzar la "vida eterna".

En Mateo, la secuencia 2, 3, 4, 5 parece prohibir crímenes en orden de gravedad descendente, y es probable que, en Exodo y Deuteronomio, el orden 1, 2, 3, 4, 5 también represente una secuencia de "peor" a "menos malo".

Digamos para terminar que Mateo es el único de los sinópticos que añade al final: "Amarás a tu prójimo como a ti mismo" (Lv 19, 18), y lo hace aparentemente como resumen y culminación de los preceptos precedentes ${ }^{6}$. La pregunta es entonces por qué, en la tradición sinóptica, se desplaza "honra a padre y madre" (1) hasta el final de la secuencia de los preceptos del decálogo. Esto merece una reflexión.

\section{Un paralelismo parcial}

Si comparamos los preceptos que Jesús menciona al joven rico en Mateo con las seis antítesis, notamos un parcial paralelismo con los preceptos "tradiciona les" ("Han oído que se dijo ...") que Jesús aduce al inicio de cada antítesis:

\section{Eljoven rico (Mt 19)}

2) No matarás.

3) No cometerás adulterio.

4) No robarás.

5) No levantarás falso testimonio.

1) Honra a tu padre y a tu madre.

6) Amarás a tu prójimo como a ti mismo.
Antítesis: "Han oído que se dijo..." (Mt 5)

2') No matarás.

3) No cometerás adulterio.

3A) Que le dé (a la mujer repudiada) acta de divorcio.

5) No perjurarás.

6A) Ojo por ojo y diente por diente. 6') Amarás a tu prójimo y odiarás a tu enemigo.

Los dos primeros preceptos de cada columna son idénticos: se trata de evitar lo peor, el homicidio y el adulterio. Los últimos preceptos de cada columna (6 y 6’) también coinciden en lo fundamental, pues "prójimo" en Lv 18, 19 significa

6. Véase Rom 13, 9: "En efecto, lo de: 'No adulterarás, no matarás, no robarás, no codiciarás' y todos los demás preceptos, se resumen en esta fórmula: 'Amarás a tu próji mo como a ti mismo". Cfr. Ga 5, 14. 
"otro judío", y "odiar" (en 6') puede significar simplemente "no hay que amar" (comparar Lc 14, 26 con Mt 10,37). Finalmente, también son similares la prohibición de falso testimonio (5) y la de perjurar (5'). Ambas cosas promueven la comunicación honesta.

Este paralelismo parcial sugiere que en las antítesis estamos ante una reflexión que se ha desarrollado a partir del esquema de los preceptos enumerados para el joven rico. Éstos expresan las exigencias fundamentales de la torah, mientras que las antítesis expresan las exigencias fundamentales de la justicia más abundante del reino.

Ya hemos dicho que el paralelismo es parcial. Los preceptos tradicionales que aparecen al comienzo de las antítesis no incluyen la prohibición del robo (4) ni el deber de honrar a los progenitores (1); pero incluyen dos preceptos adicionales: la obligación de dar a una mujer despedida un acta de divorcio (3A) y la ley del talión (6A). Para entender el significado de estas diferencias hay que considerar la justicia abundante exigida por Jesús y el Padre.

\section{La justicia mayor}

"Si su justicia no es mayor que la de los escribas y fariseos, no entrarán en el reino de los cielos" $(5,20)^{7}$. Así introduce Jesús la serie de antítesis. Al joven rico le falta algo para entrar en la vida eterna (Mt 19, 20). Y las antítesis, "lo que han oído que se dijo", se quedan cortas, les falta algo. Veamos en qué consiste la justicia abundante, mayor, del reino, comparando las dos partes de cada antítesis.

La justicia de escribas y fariseos:

"Han oído que se dijo..."

- No matar.

- No cometer adulterio.

- Dar a la mujer repudiada acta de divorcio.

- No perjurar.

- Ojo por ojo y diente por diente.

\section{La justicia mayor:}

"Pero yo les digo..."

- No encolerizarse contra el hermano (hermana). No insultar al hermano(a).

- No mirar a una mujer (ajena) deseándola (pros to epithumesai).

- No repudiar a la mujer. No casarse con una repudiada.

- No jurar en modo alguno. Decir sólo "Sî, sî"y "No, no".

- No resistir al malvado; ofrecer la otra mejilla; dar también el manto

7. Como es sabido, a la expresión "reino de Dios", Mateo prefiere su equivalente "reino de los cielos" para evitar una mención directa del santo nombre divino. 
- Amar al prójimo y odiar al enemigo.

al que pleitea para que le den la túnica; acompañar una milla extra de servicio forzado. Dar y prestar a quien lo pida.

- Amar a los enemigos, rogar por sus perseguidores. Ser perfectos como el Padre celestial que hace brillar el sol y llover por igual sobre gente justa e injusta.

$\mathrm{Al}$ joven rico le falta algo. Si quiere ser "perfecto" (teleios), debe unirse al grupo de discípulos, que, con Jesús, viven anticipadamente la novedad del reino. Son la semilla, la levadura en la masa. Son el comienzo de un pueblo de Dios para la nueva era.

Según esto, el sermón de la montaña es una catequesis para los discípulos que viven en comunidad unos cincuenta años después de la resurrección de Jesús. Deben ser sal de la tierra, luz del mundo, y de tal manera que, al ver sus obras, la gente debe dar gloria al Padre celestial y corresponder a la venida de su reinado $(5,1-2.13-16 ; c f r .28,19)$. Así como los preceptos dirigidos al joven rico resumen la torah en forma tradicional, las antítesis resumen la justicia mayor, abundante, entre los y las discípulas. Y ofrecen una clave de interpretación de la plena realización (plerosai) de la torah tal como Dios la exige para la era mesiánica. Veámoslo.

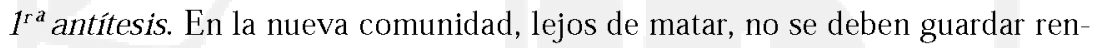
cores ni insultarse.

$2^{\text {da }}$ antítesis. Los hombres no solo evitarán el adulterio, sino que sus corazones no se desviarán hacia otras mujeres casadas $^{8}$. No deben desearlas. La palabra epithumeo es la misma que se usa en la prohibición final del decálogo, cuando habla de codiciar mujeres y bienes ajenos (Ex 20, 17 [LXX] y Dt 5, 21 [LXX]). Esta prohibición se añade a los demás preceptos del decálogo incluidos en las antítesis.

8. Como lo reconocen los comentaristas, se trata de desear la mujer de otro hombre, ya que el tema del contexto es el adulterio. "Aunque el papel de la vista en la excitación sexual masculina fundamenta lo que se dice en este texto, su preocupación es la violación del matrimonio de otro hombre y no la excitación sexual como tal" (J. Nolland, The Gospel of Matthew: A Commentary on the Greek Text, Cambridge, UK, 2005, p. 236). 
En esta segunda antítesis (y tal vez en la primera ${ }^{9}$ ) se manifiesta la importancia que, en Mateo, para Jesús tiene el corazón - o la voluntad - como fuente de obras buenas y malas (cfr 15, 18s; 23, 26; 7, 15-20 y 12, 33-35): árbol bueno, fruto bueno; hay que ser "sin doblez como la paloma" $(10,16)$ etc. Son felices los limpios de corazón $(5,8)$, a diferencia de los fariseos hipócritas de corazones impuros, por muy cumplidores de la torah que parezcan. Jesús no resta importancia a las obras, pero insiste en que las obras buenas — que son indispensables - brotan de corazones limpios.

$3^{\text {ra }}$ antítesis. A un hombre que repudiaba a su mujer, Moisés le obligaba a darle a ella un acta de divorcio (cfr Dt 24, 1) para defenderla y permitir que encontrase a otro hombre en una sociedad patriarcal donde la mujer sola era vulnerable e indefensa ${ }^{10}$. Pero Moisés toleró esta concesión debido a la dureza de corazón en Israel. No responde a la voluntad de Dios, que, en los orígenes de la humanidad, estableció el matrimonio de tal forma que dos personas llegaran a ser como una sola, e inseparables (Mt 19, 4-8; cfr Gen 1, 27; 2, 24). Los seguidores de Jesús tienen que vivir conforme a este propósito original de Dios.

La breve introducción a esta tercera antítesis ("también se dijo...") la une estrechamente con la anterior. Las prohibiciones de adulterio (2) y del deseo de la mujer ajena (2') pretenden defender los derechos del varón. A lo que Jesús, para proteger a la mujer, agrega la prohibición del divorcio (2A), que no aparece en la torah. Pero no basta un acta de divorcio para proteger a la mujer. El hombre tiene que mantenerse fiel a ella, salvo en el caso de porneia, o "inmoralidad sexual" $(5,31)^{11}$. Esto es un cambio radical. En otro contexto, según Mateo (19, 9), Jesús afirma que el hombre que repudia a su mujer y se casa con otra comete adulterio. Él comete adulterio contra ella (Mc 10, 11 lo afirma explícitamente; en Lc 16, 18 está implícito, como en Mateo). De esta forma se amplía el concepto de adulterio, que en el judaísmo es una ofensa únicamente contra los derechos del hombre con respecto a su mujer. Esta redefinición del adulterio afirma derechos paralelos de la mujer, y replantea las relaciones entre esposos en términos más igualitarios.

9. "Encolerizarse" en la primera antítesis bien puede referirse a una expresión de cólera, como en los dos ejemplos del v. 22.

10. R. B. Hayes, The Moral Vision of the New Testament: Community, Cross, New Creation, San Francisco, 1996, p. 350.

11. La excepción parece ser una adaptación de Mateo, que suaviza la prohibición absoluta, la cual se remontaría al mismo Jesús. Aquí porneia puede significar 1) adulterio, y tal vez otros desórdenes sexuales; 2) fornicación prematrimonial que hubiera comprometido la virginidad; 3) matrimonio dentro de los grados de parentesco prohibidos en Lv 18, 16-18. Cfr, Hayes, op. cit., pp. 353-356. 
$4^{\text {ta }}$ antítesis. Las primeras antítesis enseñan cómo vivir en la comunidad de discípulos. Tiene que incluir la transparencia en la comunicación. Lejos de jurar en falso $-o$ de no cumplir lo prometido ${ }^{12}$-, no se debe jurar en modo alguno, pues jurar supone desconfianza. Solo se debe decir "Sí, sî" y "No, no". El sentido de estas palabras aparece con más claridad en la Carta de Santiago $(5,12)$ : "Ante todo, hermanos, no juren ni por el cielo ni por la tierra, ni por ninguna otra cosa. Que su sí sea sí, y el no, no". La comunicación debe basarse en la transparencia que supone y construye confianza.

$5^{\text {ta }}$ antítesis. Además de limitar la venganza, la ley del talión ("ojo por ojo y diente por diente") aseguraba un castigo proporcional por daños sufridos. Las fuentes (Ex 22, 25; Lv 24, 17-21; Dt 19, 18-21) contemplan decisiones legales de tipo formal. En tiempo de Jesús, hubo intentos de sustituir la mutilación, pero se aplicaba la ley del talión para solucionar disputas legales sobre daños que había que reparar. Si alguien sufría una injusticia, tenía derecho a una recompensa proporcional. Los ejemplos brindados en esta antítesis contemplan la retribución personal, no siempre en un contexto jurídico.

Los y las discípulas de Jesús no deben vengarse, ni insistir en sus derechos ante ofensas y reclamos. El v. 39a, "no resistan al malvado", puede tener un sentido global, y sirven para introducir los ejemplos que siguen, o el sentido limitado de no oponerse a una demanda legal injusta. El v. 39b no tiene que ver tanto con la violencia sino con los insultos. El discípulo no debe desquitarse por los insultos y humillaciones que sufre, sino "ofrecer la otra mejilla", rompiendo así la eterna espiral de reclamos y venganzas. El v. 40 se refiere a un reclamo legal para recuperar una deuda, aparentemente de una persona muy pobre: "no te opongas a quien te ponga pleito por la túnica (interior). Más bien, dale también el abrigo (exterior)". Hay que prestar servicio forzado a las autoridades - como el de transportar bienes - el doble de lo exigido (v. 41). Finalmente, hay que dar a la gente (pobre) que le pide a uno (v. 42).

Esta antítesis sugiere una posible razón de por qué el "no robarás" no aparece entre los preceptos tradicionales que "se han oído". Aquí prácticamente se llega a decir, ¡Déjense robar!

$6^{\text {ta }}$ antítesis. La progresión de exigencias cada vez más radicales culmina con el deber de amar a los enemigos. Los discípulos deben amar como su Padre celestial, que hace salir el sol y hace llover sobre justos y malos por igual. Amando a sus enemigos y perseguidores, se mostrarán como hijos e hijas de este Padre. Serán perfectos (teleioi) como él — cabales-.

12. "No perjurarás, sino que cumplirás al Señor tus juramentos" (Mt 5, 33) no es una cita textual, sino una amalgama de textos como los de Lv 19, 12; Ex 20, 7; Dt 23, 21-23. 
El v. 48, "sean perfectos...", no sólo es la conclusión de la última antítesis, sino del conjunto de todas ellas. Forma una inclusio con el v. 20, que introduce las antítesis como ejemplos de la justicia abundante, que supera la justicia imperfecta, la de escribas y fariseos. "Teleios," "perfecto," significa cumplir la plena voluntad de Dios tal y como la plantean las antítesis, pues Jesús vino a "plenificar" (plerosai, Mt 5,17 ) la torah ${ }^{13}$. En los evangelios la palabra teleios sólo aparece aquí y en Mt 19, 21, donde Jesús dice al joven rico, "si quieres ser perfecto, anda, vende," etc. Al joven le "falta" unirse a la comunidad de discípulos para vivir la justicia mayor, abundante, de hijos e hijas de Dios que no guardan rencores, y sí guardan fidelidad y responsabilidad sexual, se comunican con transparencia, y no exigen derechos personales, ni se vengan cuando son insultados, sino que aman a todos, incluso a sus enemigos. Son sal de la tierra y luz del mundo.

No hay que suavizar las exigencias radicales de estos versículos. En ellas no se ofrece cualquier ejemplo, sino los que rompen esquemas y sirven para despertar y sacudir - y para convertirnos a una mentalidad y una praxis diferentes. Por otra parte, aunque hay que tomar en serio las imágenes - chocantes: ofrecer la otra mejilla y dar la túnica - no hay que tomarlas al pie de la letra o aplicarlas rígidamente. Cuando abofetearon a Jesús, él respondió (aunque sólo en Juan $18,22 \mathrm{~s})$. Y si en tiempos de Jesús, normalmente sólo se usaban dos piezas para vestir, habría que pensar dos veces dar el manto después de perder la túnica. Tampoco hay que aplicar las medidas más allá de lo debido. Una cosa es ofrecer la mejilla propia y otra muy distinta ofrecer la mejilla ajena (R. de Sivatte). Una cosa es no insistir en los derechos propios y otra muy distinta no defender los derechos ajenos, sobre todo de la gente más vulnerable ${ }^{14}$.

\section{Una ética globalizante}

En las antítesis se mencionan ejemplos determinados, pero éstos son más que ejemplos sueltos y sugerentes de la justicia del reino. Son tan ilustrativos que otorgan a las antítesis un carácter globalizante, como también lo hacen los preceptos del decálogo en la historia del joven rico. Y valen para todo el judaísmo y el cristianismo. El papel que la segunda tabla del decálogo juega en la estructuración de las antítesis pone de manifiesto el carácter globalizante de éstas. Es cierto que el autor de Mateo se sirvió de un sermón original en arameo para elaborar su propio sermón, como lo demuestran los estudios linguísticos de los sermones en Mateo 5-7 y Lucas 6 (el sermón de la llanura). Mateo plasmó las

13. En la Septuaginta teleios suele traducir tammim (entero, íntegro), como en Dt 18, 3, contra la práctica de cultos ajenos a Yahvé: "Serás íntegro (tamim, teleios) con Yahvé tu Dios”. Cfr. J. Jeremias, Teología del nuevo Testamento, Vol. I: La predicación de Jesús, $2^{a}$ ed., Salamanca, 1974, p. 213.

14. Aun así, "no hay fundamento alguno en el Evangelio de Mateo para justificar la idea de la violencia en defensa de terceros" (Hayes, op. cit., p. 324). 
dos antítesis finales usando material del sermón arameo (cfr. Lc 6, 27-36) e incorporando material como el de Lc 16, 17-18 (sobre la torah y el divorcio), que también proviene de fuentes comunes de Mateo y Lucas (la "fuente Q"). Pero, cuando comparamos las antítesis con la respuesta al joven rico, vemos cómo Mateo se sirvió de los preceptos enumerados en esa respuesta para estructurar sus seis ejemplos de la justicia abundante del reino. Después, amplió sus reflexiones, sirviéndose de materiales como Marcos 10, 2-12, sobre el divorcio, y la tradición que prohíbe juramentos, reflejada en Santiago 5, 12.

\section{La familia nueva}

Las antítesis esbozan un ethos nuevo para las comunidades de discípulos de Jesús. Ellos y ellas forman parte de la gran familia de Dios, alternativa a las familias naturales, cuyos reclamos se subordinan ahora a las exigencias del reino. En Mateo, Jesús advierte que su mensaje provoca divisiones familiares, y quien ama a sus parientes más que a él no es digno de él $(10,35-37)$. A uno que le pide ir a enterrar a su padre antes de seguirle, Jesús le plantea tajantemente la prioridad del reino $(8,22)$. Quienes escuchan la palabra de Dios y la ponen por obra son madres, hermanos y hermanas de Jesús $(12,46-50)$. Y por ello, como Jesús, no tienen más que un solo Padre $(23,8)^{15}$.

Se puede sospechar que la secuencia de los mandamientos en la historia del joven rico refleja estas prioridades. El precepto de honrar padre y madre ha pasado del primer lugar en la segunda tabla del decálogo (como aparece en todas las versiones veterotestamentarias, hebreas y griegas) al último lugar en las tres versiones de la historia del joven. Los y las discípulos han dejado "casas, hermanos, hermanas, padre, madre, hijos o campos" para seguir a Jesús. En la comunidad de discípulos recibirán cien veces más familiares y bienes (19, 29). Por ello, no deben andar preocupados por su seguridad ni aferrarse a sus derechos. Su Padre los cuidará $(6,25-34)^{16}$. Pueden, incluso, dejarse robar, dar prestado sin esperar recompensa. Sin embargo, aunque el reino y la fraternidad cristiana desplazan a la familia humana, el matrimonio es inviolable, debido a la dignidad de ambos esposos y a la voluntad original de Dios para ellos.

Las antítesis mencionan a los "hermanos(as)" cuatro veces $(5,22.23 .24 .47)$. A partir de la última antítesis, el sermón de la montaña menciona al Padre celes-

15. Lucas incluye textos paralelos a éstos, y otros textos adicionales, que relativizan la importancia de la familia y de los deberes familiares: Cfr. Lc 2, 48-51; 9, 61s; 11 , $27 \mathrm{~s}$.

16. El tema de la Iglesia como familia de Dios está ampliamente presente en las tradiciones del NT. Cfr. 1 Pe 4, 17; 1 Tm 3, 15; Hb 3, 6; 10, 21; Ga 6, 10; 2 Co 6, 18. Debido a la ambigüedad de las palabras oikos, oikia, que significan casa y también familia, este tema no siempre aparece con claridad en las traducciones. 
tial 16 veces $(5,45.48 ; 6,1.4 .6[$ bis].8.9.14.15.18[bis]. 26.32; 7, 11.21). Así, el contexto de las antítesis es el de la nueva comunidad que reproduce la seguridad familiar en base a la confianza en el Padre y al amor fraterno ${ }^{17}$. Esto posibilita la superación del temor, la generosidad (dar y pedir prestado) y la ruptura con la secular espiral de violencia.

\section{Ley y evangelio}

Hasta muy recientemente, parte importante de la exégesis moderna insistía en la discontinuidad entre el judaísmo y Jesús, entre torah y evangelio. Tanto las reproducciones del Jesús histórico, producto de las "búsquedas de Jesús", como la interpretación de los evangelios reflejaban esta ruptura ${ }^{18}$. Y las antítesis, en particular, servían como ilustración clara de cómo Jesús (o al menos Mateo) había dejado de lado algunos preceptos de la ley, por ejemplo, en vv. 32, 34, 39, 44 de Mt 5.

No cabe duda de que hay discontinuidad entre torah y evangelio, pues el vino nuevo requiere odres nuevos. Pero con frecuencia se ha exagerado la ruptura, ignorando cómo Mateo, en particular, presenta a Jesús como el mesías, el judío cabal. Sin comprenderlo, es imposible integrar Mt 5, 17-19 en el mensaje cristiano.

No es ahora el momento de tratar en detalle la relación entre torah y evangelio. Pero lo dicho hasta aquí, ya arroja luz sobre el tema. La justicia más abundante del reino da cumplimiento pleno (plerosai, Mt 5,17 ) a la torah. Jesús no anula sus preceptos, y las antítesis, en particular, no los repudian. Lo que hace es radicalizarlos, intensificarlos. Por eso, "antítesis" no es la palabra más adecuada para referirse a las pares de contenidos. Lo que hace Jesús es exigir algo más que la letra de la ley. En este sentido, E. P. Sanders parafrasea así las antítesis ${ }^{19}$ :

No sólo no matar, sino no encolerizarse.

No sólo no cometer adulterio, sino no mirar a la mujer con lujuria.

No divorciarse, a pesar del permiso de Moisés ${ }^{20}$.

17. Aunque "adelfos" ("hermano/a") puede significar pariente natural, o hermano judío, en nuestra opinión en las antítesis se refiere a "otro miembro de la comunidad cristiana".

18. Un recorrido de la literatura sobre el Jesús histórico puede verse en E. P. Sanders, Jesus and Judaism, Filadelfia, 1985, pp. 23-58. Impulsada por la misión a los gentiles, la supresión selectiva de algunos preceptos de la torah (respecto a la circuncisión, la dieta, el sábado, culto del templo, etc.) aumenta en las tradiciones neotestamentarias posteriores. Pero Mateo sobre todo afirma la plena validez de la torah.

19. E. P. Sanders, The Historical Figure of Jesus, Nueva York, 1996, pp. 210 s.

20. "Moisés no mandó el divorcio, lo permitió; y prohibir lo que él permitió de ninguna manera equivale a permitir lo que el prohibió... El divorcio en sí no es un estatuto: no es ni prohibido ni obligatorio". Respecto al divorcio, Jesús "no dice nada que condu- 
No jurar en modo alguno. (Obviamente nadie perjurará jamás.)

La ley dice, "ojo por ojo...". Pero yo les digo, no resistir al malvado. [Etc.]

... (El mandamiento "ojo por ojo" limita la retribución, no la exige. ...) ${ }^{21}$.

Amar a sus enemigos igual que a sus prójimos.

La segunda mitad de cada par plenifica (plerosai) la primera. Afirma a donde apunta la letra del precepto. No basta no matar, no cometer adulterio y no perjurar. Hay que ir más allá. El deber de dar acta de divorcio busca proteger a la mujer repudiada, pero esta letra no basta. "Ojo por ojo" busca limitar la venganza, pero Dios quiere mucho más. Estos preceptos son concesiones a la dureza del corazón. Pero Jesús exige - y el Padre realiza - un cambio de corazón. Jesús exige más que la letra en base a la voluntad del Padre, a su intención original al dar el precepto. Jesús conoce esta voluntad porque está lleno del Espíritu (Mt $3,16)$. "Todo me ha sido entregado por mi Padre, y nadie conoce al Hijo sino el Padre, ni al Padre le conoce nadie sino el Hijo, y aquel a quien el Hijo se lo quiera revelar" (Mt 11, 27). Jesús conoce al Padre y discierne el espíritu que da vida a la letra de la torah.

La justicia abundante del reino trasciende la letra. No sólo se exige más, sino que se supera el legalismo moral. Por venerable que sea la expresión ${ }^{22}$, Jesús no promulga una ley nueva ${ }^{23}$. Aunque hay que cuestionar una exégesis, muchas veces de inspiración protestante, que exagera la ruptura de Jesús con la torah, también hay que cuestionar un énfasis exagerado y típicamente católico en los preceptos. Este énfasis tiene raíces muy profundas. Desde el siglo II, Mateo, como primero en la colección de evangelios, gozó de una cierta preferencia en la Iglesia - y Mateo es el evangelio que recalca la obligación de cumplir todos los preceptos $(5,19 ; 23,3.23 b)$. Pronto la Iglesia de occidente se desarrolló en medio de una

ciría a la desobediencia de la ley, y no puede decirse que él se opone a ella" (Sanders, Jesus and Judaism, pp. 256s).

21. Sin embargo, Lv 24, 17-21 y Dt 19, 18-21 exigen la aplicación de la ley del talión en las situaciones formales que contemplan. Jesús rechaza este criterio, al menos para justificar la retribución personal.

22. Gracias, en gran parte, a la autoridad de santo Tomás en la teología católica es tradicional caracterizar la moral cristiana como "ley nueva". Cfr Summa Theologica I-II, 106-108 y Catecismo de la Iglesia Católica, nn. 1965-1974.

23. "Dados sus presupuestos conceptuales teocéntricos, al evangelista [Mateo] le habría resultado imposible elevar a Jesús a la categoría de legislador. Para él, las palabras de Jesús ( fr 6,$10 ; 7,21 ; 12,50 ; 18,14 ; 21,31)$, sus acciones $(9,13 ;$ cfr 12,7$)$ y su vida toda $(26,42)$, estaban enteramente centradas en el cumplimiento de la voluntad de su Padre. Además, parece dudoso que las sentencias de Jesús ... puedan ser entendidas, de acuerdo con su género, como dotadas de carácter 'legal', sea cual fuere el concepto que se tenga de la ley" (Michael Theobald, "El fundamento bíblico de la doctrina moral de la Iglesia”, en La teología moral, ¿en fuera de juego?: Una respuesta a la encíclica "Veritatis splendor", Dietmar Mieth, dir, Barcelona, 1995, p. 45. 
cultura marcada por el derecho romano, lo que dejó profundas huellas en la moral cristiana. La consecuencia es que, a lo largo de toda su historia, el legalismo ha sido tentación para la Iglesia en occidente, y en particular para la Iglesia católica romana. Sin embargo, "la revelación bíblica no admite el puesto central que la moral tradicional católica venía otorgando a la Ley"24.

Los preceptos tienen su lugar en la moral cristiana, pero no son lo principal. Es cierto que al joven rico Jesús le recuerda los preceptos del decálogo cuando le pregunta por la vida eterna, pero este joven no es cristiano. Jesús le recuerda lo mínimo necesario, para luego invitarle a seguirlo. El sermón de la montaña, en cambio, se dirige a cristianos y cristianas, que ya se han convertido y creído en el evangelio. Para estas personas la catequesis y la moral comienzan con las bienaventuranzas. Éstas no son leyes, sino buenas noticias que esbozan el perfil del discípulo (y del mismo Jesús). No plantean una moral de preceptos, sino de "actitudes," como suele decirse, pero en el sentido integral. Describen qué clase de persona es seguidora de Jesús: los discípulos de Jesús son pobres en espíritu. Esto quiere decir que son mansos, están afligidos por las injusticias del mundo, anhelan la justicia, son limpios de corazón, practican la misericordia, trabajan por la paz y sufren por la causa de la justicia. A continuación, Mateo enfrenta un problema pastoral apremiante para los miembros de su comunidad, acusados de traicionar al judaísmo, y tentados, tal vez, a abandonar la torah: ¿qué papel juega la torah y sus preceptos en la vida de quienes siguen a Jesús? A partir de ahí, y por esa razón, tenemos las antítesis. Éstas llaman a ir más allá de la letra de los preceptos, por útiles y necesarios que éstos puedan ser.

\section{Toda la torah y los profetas}

Conocer al Padre a la manera de Jesús (cfr Mt 11, 27) permite conocer su voluntad, en toda su sencillez y profundidad. Permite discernir la justicia mayor que se resume en la entrega total a Dios y el amor fraterno. De estos dos mandamientos dependen toda la torah y los profetas (Mt 20,37-40). Llama la atención que Mateo presenta otros resúmenes de la torah sin mencionar el amor a Dios: al joven rico Jesús sólo le plantea los preceptos de justicia interhumana $(19,18 \mathrm{~s})$; resume "la torah y los profetas" en la regla de oro: hacer al prójimo lo que uno quiere que se la haga a uno $(7,12$, hacia el final del sermón); y dice que ayudar a los más humildes en su necesidad será el único criterio del juicio de las naciones (25, 31 ss). ¿Por qué no se especifican las obligaciones con Dios en estos resúmenes?

24. Francisco Lage, "Alianza y Ley", en Conceptos fundamentales de ética teológica, M. Vidal, ed., Madrid, 1992, p. 37). El mismo santo Tomas dice que "la ley nueva principalmente es la misma gracia del Espíritu Santo, que se da a los fieles de Cristo... la ley nueva es principalmente la ley [de la gracia] infusa; secundariamente es la ley escrita" (S.T. I-II, q. 106, a. 1). Cfr. Catecismo de la Iglesia Católica, n. 1966. 
Alguien ama a Dios al hacer lo que Dios quiere. Y lo que Dios quiere es, evidentemente, que se ame al prójimo, especialmente a quien tiene necesidad. "Quiero misericordia [gr. eleos, hebr. hesed] y no sacrificios" (Mt 9, 13; 12, 7). El contexto mateano de las dos citas del profeta Oseas $(6,6)$ demuestra que "sacrificios" se refiere a la pureza cultual y al culto en general: Dios quiere misericordia más que culto.

Desde la época postexílica predominaba en Israel la teología sacerdotal con su énfasis en el culto y su tendencia legalista. En tiempos de Mateo la interpretación rabínica de la torah escrita, y la misma torah oral (halaja), reflejaban esta preocupación por el culto (sábado, pureza, etc.) a costa de la misericordia. En Mateo la doctrina más "profética" del maestro Jesús se opone a una doctrina sacerdotal estrecha y truncada. Encontramos la voluntad de Dios en "la torah y los profetas" $(5,17 ; 7,12 ; 22,40)$, o en la torah interpretada desde la perspectiva profética.

Para Mateo, el amor y el mismo Jesús se convierten en clave de interpretación de los preceptos. La torah sigue siendo válida siempre, pero no todos los preceptos pesan lo mismo. Lo más importante de la torah - literalmente "lo que pesa más" - es "la justicia, la misericordia y la fe" $(23,23)$. Estas palabras - krisis, eleos y pistis en griego - traducen las hebreas mishpat, jesed y emeth. Mishpat significa "justicia" social muy concreta, teniendo con frecuencia matices jurí$\operatorname{dicos}^{25}$. Jesed-y-emeth es una hendíadis que significa "misericordia fiel", y por tanto confiable. En resumen, la justicia (en el sentido general de dikaiosune) que cumple con la torah es el amor (agape), y este amor es justicia liberadora y misericordia fiel. Hoy lo podemos historizar en forma del doble principio de la praxis cristiana: el principio liberación más el principio misericordia.

En conclusión, el sermón de la montaña no propone una moral de leyes, ni de deberes que hay que cumplir para conseguir la salvación. (Cuando el joven pregunta: “Qué he de hacer de bueno para conseguir la vida eterna?”, Jesús responde que sólo Dios es bueno. Es cierto que asesinos y adúlteras no consiguen la vida eterna, pero tampoco se consigue por obras humanas). Tampoco propone una ética perfeccionista para una élite moral o una secta aislada; ni un ideal imposible que lleva a la desesperación; ni una "ética interina" basada en la expectativa de una parusia inminente ${ }^{26}$. La justicia más abundante es para toda la humanidad. Su finalidad es hacer de ella una gran familia de Dios.

Al final del evangelio de Mateo, Jesús envía a sus discípulos: "Vayan, pues, y hagan discípulos a todas las gentes bautizándolas ... y enseñándoles a guardar todo lo que yo les he mandado". Parece una tarea sobrehumana llevar a la prác-

25. Comparar este significado con dikaiosune. Ver nota 1.

26. Cfr J. Jeremias, Die Bergpredigt (Stuttgart, 1959), que rechaza estas alternativas. 
tica todo lo que Jesús ha mandado, pero no es imposible por la presencia constante de él -Emmanuel: "He aquí que yo estoy con ustedes todos los días hasta el fin de los siglos" $(28,19-20)$.

Mientras las bienaventuranzas de Mateo bosquejan el perfil del discípulo de Jesús, las antítesis que siguen esbozan cómo los y las discípulas deben vivir en comunidad como familia nueva. Plantean un modo revolucionario de vivir que invita y reta a las comunidades cristianas de hoy a ser en verdad luz del mundo y ciudad puesta en la cima de un monte, manifestando con sus obras la justicia y misericordia de Dios, única fuerza capaz de vencer el pecado que configura la vida del mundo de hoy. 